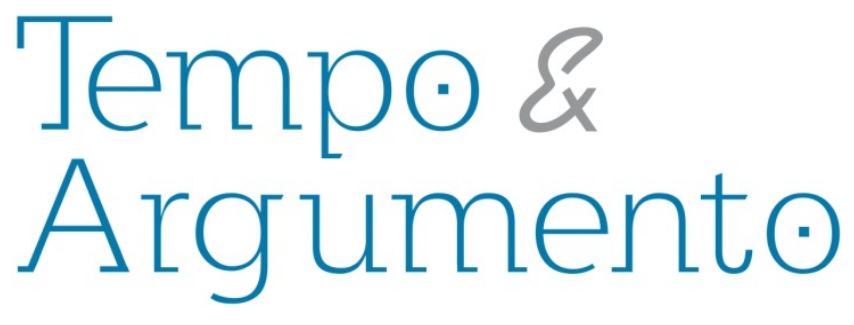

\title{
Militância estudantil e memórias dos anos $1960^{1}$
}

\begin{abstract}
Resumo
O artigo explora entrevistas de militantes estudantis dos anos 1960 que atuaram na UFBA. Investiga essa memória militante a respeito do movimento estudantil e suas representações sobre festa na política, violência, repressão e usos políticos do passado. Reflete sobre o esquecimento nas narrativas das lutas desenvolvidas pela militância estudantil antes do golpe de 1964. Sugere que investigar as continuidades e rupturas entre a militância estudantil antes do golpe e a que atuou na resistência à ditadura pode contribuir para novas problemáticas historiográficas. Problematiza a associação entre geração de 1960 e geração de 1968.
\end{abstract}

\section{Antonio Mauricio Freitas Brito}

Doutor em História pela Universidade Federal da Bahia (UFBA). Professor do Programa de

Pós-Graduação em História Social da

Universidade Federal da Bahia (UFBA).

Salvador, Bahia - BRASIL mafbrito@hotmail.com

Palavras-chave: Movimentos estudantis - Brasil.

Estudantes - Atividades Políticas. Ditadura - Brasil.

Memórias Estudantis. Geração de 1960 - Geração de 1968.

\section{Para citar este artigo:}

BRITO, Antonio Mauricio Freitas. Militância estudantil e memórias dos anos 1960. Revista Tempo e Argumento, Florianópolis, v. 9, n. 21, p. 94 - 131. maio/ago. 2017.

DOI: $10.5965 / 2175180309212017094$

http://dx.doi.org/10.5965/2175180309212017094

\footnotetext{
${ }^{1}$ Gratidão aos pareceristas anônimos da Tempo e Argumento pelas sugestivas observações incorporadas na versão final do texto. Agradeço também aos ricos comentários feitos por Iracélli Cruz Alves e Luís Flávio Godinho.
} 


\title{
Student activism and memories in the $1960 \mathrm{~s}$
}

\begin{abstract}
This article describes interviews of student activists who protested at the UFBA during the 1960s. It discusses the reasons why some student protests occurred before the 1964 coup d'etát have been forgotten. In addition, this article aims to show how identifying similarities and differences between previous protests and the resistence against the military dictatorship can improve the historiography of student moviments from 1960s. Finally, it explores the connections between 1960 and 1968 generations of students.
\end{abstract}

Keywords: Student movement - Brazil. Students Political activities. Brazilian Military Dictatorship. Students Memories. 1960 Generation - 1968 Generation.

Este artigo analisa entrevistas realizadas com ativistas que atuaram no movimento estudantil (ME) na Universidade Federal da Bahia nos anos 1960. ${ }^{2}$ Atento às novas possibilidades de pesquisa com as mídias sociais, dialoga com depoimentos concedidos à Comissão Milton Santos de Memória e Verdade da UFBA disponíveis no YouTube. ${ }^{3}$ Incorpora fragmentos memorialísticos produzidos por outros militantes estudantis que

2 As entrevistas foram realizadas no segundo semestre de 2002 para a pesquisa de mestrado posteriormente publicada (BRITO, 2016). Este artigo explora relatos de Amílcar Baiardi, Fernando Alcoforado, Othon Jambeiro, Sérgio Passarinho - estudantes da UFBA em 1964. Aécio Pomponet Sampaio, Benedito Veiga, Gey Espinheira, João Coutinho, José Sérgio Gabrielli, Juca Ferreira e Vitor Hugo ingressaram na universidade após o golpe. Também foi utilizado o testemunho escrito de Ubiratan Castro de Araújo, que entrou na universidade após 1964.

${ }^{3}$ Disponível em <https://www.youtube.com/playlist?list=PLSIGD7-rHf2VB1KteRZtOAHhUpmrdCrua>. Acesso em 23/08/2017. Neste endereço virtual encontram-se links para 30 vídeos disponíveis na íntegra. Entre estudantes e professores, 29 pessoas prestaram depoimentos no primeiro trimestre de 2004. Os relatos oscilaram entre 25 e 90 minutos e foram orientados por um roteiro comum elaborado pela Comissão com três questões: "como você foi atingido pelo regime militar implantado em 1964 e que consequências isso teve em sua vida?; a UFBA, por meio de suas instâncias ou de seus membros, teve algum papel nos fatos em que você esteve envolvido?; você conhece ou presenciou outros fatos relacionados ao regime militar envolvendo estudantes, funcionários ou professores da UFBA?". 
atuaram na direção da União Nacional dos Estudantes (UNE) e/ou no eixo Rio-São Paulo. ${ }^{4}$ Ressalta a memória militante como objeto de investigação histórica e se soma a alguns trabalhos produzidos sobre a história do ME brasileiro dos anos 1960 que utilizaram as fontes orais e/ou problematizaram a memória construída pela militância (OLIVEIRA, 2001; VICENTE, 2006; ARAÚJO, 2007; MULLER, 2007; MULLER, 2014).

Diversos autores enfatizam a relação entre história oral e tempo presente ${ }^{5}$ (FERREIRA, 1996; CHAUVEAU, TÉTART, 1999). Para Rousso (2001, p. 98), um indivíduo que fala sobre sua experiência do passado "não falará senão do presente, com as palavras do hoje, com sua sensibilidade do momento, tendo em mente tudo quanto ele possa saber sobre este passado que ele pretende recuperar com sinceridade e veracidade". De acordo com Gallian (1996), o documento da história oral deve ser entendido como uma fonte sobre o passado e o presente, pois, da mesma forma que o presente é vivido no nível subjetivo, o passado é experimentado subjetivamente no presente. Ecléa Bosi (1983, p. 17) acrescenta uma boa sugestão metodológica: “lembrar não é reviver, mas refazer, reconstruir, repensar, com imagens e ideias de hoje, as experiências do passado". Para ela, o que rege, em última instância, "a atividade mnemônica é a função social exercida aqui e agora pelo sujeito que lembra" (BOSI, 1983, p. 23).

Estes ativistas frequentaram cursos na Faculdade de Filosofia, Escola Politécnica, Economia, Faculdade de Direito, Instituto de Física e Escola de Agronomia da Universidade Federal da Bahia. Muitos se tornaram professores universitários, profissionais liberais, dirigentes de estatais ou membros do executivo. Em 2002, duas pessoas eram militantes do Partido dos Trabalhadores, enquanto uma era filiada ao

\footnotetext{
${ }^{4}$ Marcello Cerqueira, Altino Dantas, Daniel Aarão Reis e Franklin Martins.

${ }^{5}$ Convém sublinhar que a maioria das entrevistas foi desenvolvida no segundo semestre de 2002 - período marcado pela onda neoliberal na América Latina e por uma atmosfera de defensiva da luta socialista em nível internacional, após a queda do Muro de Berlim como emblema da crise do socialismo burocrático. Tendo como marco importante a derrota da resistência armada à ditadura militar no Brasil, acrescentese um processo de crítica e autocrítica que marcou a militância de esquerda brasileira, no memorialismo político, no interior das organizações políticas e no nível da reflexão individual (RIDENTI, 1993). Acrescente-se que era um período de disputa eleitoral em que o Partido dos Trabalhadores canalizava a esperança de setores de esquerda nas eleições presidenciais com a candidatura Lula. De modo difuso, esses vetores marcaram os itinerários intelectuais e políticos e devem ser considerados na análise dos relatos dos militantes e suas leituras sobre o passado. Ao mesmo tempo, o texto não pretende investigar o impacto destas e outras experiências e contextos na visão de mundo de cada ativista.
} 
Partido Verde. Alguns continuavam no campo da esquerda ${ }^{6}$, enquanto outros redefiniram suas posições.

Esses militantes são homens que participaram do movimento estudantil de diferentes lugares institucionais: alguns foram membros de Diretórios Acadêmicos (DAs) e Diretório Central dos Estudantes (DCE); outros atuaram na União dos Estudantes da Bahia (UEB) e outros não ocuparam cargos em direções de entidades. Todos são egressos da UFBA. A maioria se engajou em organizações de esquerda como Ação Popular (AP), Partido Comunista Brasileiro (PCB), Partido Comunista do Brasil (PCdoB), Política Operária (POLOP) e Esquerda Independente (EI). No caso dos outros ativistas estudantis - os chamados independentes, segundo o jargão político da época -, a influência desse ideário de esquerda existia, mas era difusa. Além da disponibilidade para conceder o relato, os critérios de escolha dos entrevistados foi contemplar setores da direção política de organizações políticas e do $\mathrm{ME}$, bem como ativistas políticos que não ocupavam lugar de destaque na "vanguarda" à época. Portanto, houve um esforço para acessar uma diversidade de leituras, graus de engajamento, perspectivas e organizações políticas à época.

Lidar com essa pluralidade de lembranças implica atentar para algumas características da memória. Em primeiro lugar, ela é seletiva, parcial e interessada (ALCAZAR I GARRIDO, 1993). Além disto, sofre flutuações em função do presente, ou seja, a memória é construída socialmente, experimenta mudanças, negociações e transformações. A memória também é fundamental para a construção da identidade individual e coletiva e para a afirmação de coesão ou clivagens no grupo (POLLACK, 1989; POLLACK, 1992).

As entrevistas enfatizaram tanto os aspectos comuns ao ME no enfrentamento da ditadura militar quanto algumas tensões e conflitos internos. As narrativas são problematizadas e inspiradas em Portelli: as fontes orais como fatos e representações. Segundo o autor,

\footnotetext{
${ }^{6}$ A palavra esquerda é utilizada neste texto para caracterizar "forças políticas críticas da ordem capitalista estabelecida, identificadas com a luta dos trabalhadores pela transformação social" (RIDENTI, 2000, p. 17).
} 
Representações e "fatos" não existem em esferas isoladas. As representações se utilizam dos fatos e alegam que são "fatos"; os fatos são reconhecidos e organizados de acordo com as representações; tanto fatos quanto representações convergem na subjetividade dos seres humanos e são envoltos em sua linguagem. Talvez essa interação seja o campo específico da história oral, que é contabilizada como história com fatos reconstruídos, mas também aprende, em sua prática de trabalho de campo dialógico e na confrontação crítica com a alteridade dos narradores, a entender representações (PORTELLI, 2001, p. 111).

\section{Estudantes, política e festa}

Para ilustrar a força das sugestões teóricas elencadas, Gey Espinheira ${ }^{7}$ alegou que sua saída de determinada corrente política ocorreu devido à sua discordância quanto ao perfil exigido de militante muito sisudo e austero. Apontou que suas crenças políticas implicavam bom humor e alegria; saiu da organização

quando foi censurado porque fazia farra, tinha amigos da esquerda festiva. Tinha que ser austero e fazer farra escondida. Eu disse que "não concordo com isso não". Em todo meu projeto político, gosto de viver com alegria, com satisfação e na busca da felicidade, bem humorado e alegre. [...] [Eles] eram chatos. Não tinha outro assunto que não fosse política.

Ao ser perguntado sobre como a face lúdica se manifestava nas passeatas, narrou em tom sério:

Nossas passeatas eram violentas, não eram lúdicas não. Nossa participação era como militante. Palavras de ordem, faixa, panfleto, discurso. Não tinha tempo para o lúdico. Naquele tempo a gente não brincava em passeata. A passeata era coisa levada a sério. Você cantava música e tome-lhe pedras, tome-lhe tiro. [...] o normal era sermos dissolvidos à bala.

Este relato aparentemente contradiz a imagem construída pelo entrevistado sobre o seu perfil político à época. O depoimento foi moldado pela ênfase na violência da repressão. Em entrevista distinta, Aécio Pamponet Sampaio ${ }^{8}$ afirmou que

\footnotetext{
7 Gey Espinheira nasceu em 1946 e fez graduação em Ciências Sociais na Faculdade de Filosofia UFBA. Militou na AP e PCdoB entre 1966 e 1968. Foi presidente do DA de Filosofia em 1967. Fez parte de um grupo de ação cultural. Tornou-se Professor Universitário e membro do Departamento de Sociologia. Faleceu em 2009.

${ }^{8}$ Aécio Pamponet Sampaio ingressou no curso de Ciências Sociais da Universidade Federal da Bahia em 1967. Já tinha militância secundarista no movimento secundarista (Central). Em outubro do mesmo ano foi eleito presidente do DA de Filosofia. Na época pertencia à Ação Popular. Preso três vezes, teve sua
} 
eram passeatas aguerridas [...] você saía de lá com a disposição do confronto. Não havia, por exemplo, a preocupação com o espetáculo, de você fazer representações, captar um pouco a simpatia da população a partir disso. Era uma coisa que você ia [...] levar sua palavra de ordem esperando que a polícia viesse reagir contra você [...] confronto na rua, bomba, prisão do outro, gente ferida.

O mesmo entrevistado falou que, embora fosse comum a existência de festas para dançar bolero, "não havia essa questão da festa na política. A preocupação [...] era com o discurso, com a conscientização política. Quer dizer a gente via muito a festa como alienação". Estas narrativas parecem se contrapor a uma visão que analisa a militância dos anos 1960 como uma aventura estudantil adolescente. Essa noção povoa o senso comum e reproduz representações dos jovens como românticos e ingênuos.

Sem desconsiderar os ciclos repressivos que reverberaram na ação política estudantil entre 1965-1968, as mediações encontradas na militância juvenil envolvendo política, humor e festa nos anos 1960 merecem ser inventariadas. Achados empíricos que ajudem a trazer novas problemáticas para a historiografia poderão ser encontrados e contribuirão para reflexões teórico-metodológicas instigantes, ampliando a noção de participação e política para além da dinâmica institucional do ME e dos embates diretos de rua envolvendo o ME e o Estado.

Essa ampliação da escala de observação pode captar uma diversidade maior de experiências que moldaram a ação estudantil e a memória militante. Sendo coerente com o postulado e exemplificando, mesmo a repressão ao XXX Congresso da UNE (a "queda de Ibiúna", São Paulo) em outubro de 1968 teve lances cômicos e festivos. Ilustrando a diversidade de memórias, Sérgio Passarinho ${ }^{9}$ narrou alguns detalhes na prisão:

matrícula cassada em 1969. Ele depôs na décima primeira oitiva da Comissão Milton Santos de Memória e Verdade da UFBA, realizada no dia 06 de maio de 2014, no auditório da Faculdade de Comunicação. Disponível em < https://www.youtube.com/watch?v=AtXBvD3q9SE>. Acesso em: 27/08/2017.

9 Sérgio Passarinho entrou em 1964. Militou no PCB. Foi Presidente do DA de Arquitetura (1965), VicePresidente do DCE da UFBA (1966) e Presidente UEB (1967). Formou-se em dezembro de 1968, mas foi enquadrado pelo Al-5. Partiu para o exílio. Concedeu depoimento em 22/04/2014 à Comissão Milton Santos de Memória e Verdade UFBA. Disponível em <https://www.youtube.com/watch?v=W28VooEq1Gs>. Acesso em 20/08/2017. 
Durante a entrevista com o ex-Presidente da União dos Estudantes da Bahia em 1967-1968, emergiram outras lembranças festivas em relação à viagem de retorno de São Paulo para Salvador, após o desbaratamento do Congresso, prisão e soltura dos estudantes. De acordo com o entrevistado, o clima foi

Maravilhoso. Festa. Batucada. Tudo era motivo de [festa]. Até o pessoal que vinha escoltando, armado e tal se descontraiu depois que percebeu que ninguém tava querendo fugir. [...] A gente sabia que por mais tempo que ficasse preso ia ser solto.

Aécio Pamponet Sampaio ressaltou:

Depois na volta no ônibus, viemos escoltados com o pessoal da Polícia Militar de São Paulo. E eu te digo que em 1 hora de viagem eles já estavam na gandaia com a gente. E eu lembro de [um estudante] com a metralhadora do [policial] no ombro e o quepe do soldado dançando. Aí dava dinheiro pra eles comprarem cachaça no meio do caminho, eles pararam o ônibus. Aí botava a garrafa coberta, soldado dançando, todo mundo bebendo, uma viagem divertidíssima [...] e eles sentindo que ninguém tava ali preso pra fugir no meio da estrada [...]. Estávamos felizes porque estávamos voltando pra casa, apesar de voltarmos num ônibus escoltado pela polícia militar de São Paulo.

Um acontecimento ilustra a força do humor na prática política. Em agosto de 1968, uma das passeatas foi violentamente reprimida pela polícia. Um grupo de estudantes que estava reunido na residência universitária percebeu alguém na rua com comportamento suspeito. Depois de uma abordagem, concluiu que se tratava de Edson Ferreira de Souza um agente policial, provavelmente cumprindo função de espionagem (BRITO, 2008). Os estudantes vendaram-lhe os olhos encaminhando-o à assembleia estudantil que se desenrolava. Depois do espetáculo da entrada e catarse coletiva pelo poder estudantil 
diante da passividade do policial "sequestrado", o deboche foi a arma de resistência segundo João Vicente ${ }^{10}$ :

Quando ele chegou foi um impacto violento, todo mundo ficou assombrado [...]. Debateu-se na assembleia o que fazer com ele, decidiu levar para a Escola de Veterinária. [...] Tudo ali era uma mata geral, então ele ficou lá a noite toda naquela mata e quando foi uma certa hora da madrugada [...] deixou ele [de cueca] na pista de Ondina, lá na praia [risos].

Sem abrir mão da irreverência, o trote é outro aspecto do comportamento estudantil marcado por política e festa. Ainda que eventualmente marcado por práticas violentas, o ritual reunia componentes de crítica ao status quo. Na véspera do golpe, estudantes de Geologia organizaram um trote nas ruas do centro de Salvador em solidariedade à Revolução Cubana. Em alguns momentos, a imprensa criticava o que considerava "excessos" e exigia controle. O ritual dos estudantes de Economia de 1968 incorporou críticas aos Estados Unidos e expressou solidariedade à resistência vietnamita (BRITO, 2008).

A formatura é mais um exemplo que sugere a existência da mediação entre festa e política. Comemoração e alegria por parte dos formandos pela conclusão do curso conviviam com propaganda de posições políticas e ideológicas sobre a conjuntura nacional e internacional. Antes e depois do golpe, havia disputas nas turmas pela definição do orador. Ex-Presidente da União dos Estudantes da Bahia (UEB), Sérgio Gaudenzi ${ }^{11}$ voltou da prisão e ainda foi orador de turma. Argumenta que foi uma surpresa porque a turma não era "tão à esquerda assim”, se dividiu mas ganhou na votação.

Após o golpe de 1964, numa das reuniões do Conselho Universitário, o reitor Miguel Calmon criticou os "excessos" cometidos pelos oradores de turma. Na paisagem

\footnotetext{
${ }^{10}$ João Coutinho era estudante de Física. Foi membro do Diretório Acadêmico de Física. Militou na Política Operária. Teve seu direito de matrícula cassado em 1969. Depôs na Comissão Milton Santos de Memória e Verdade da UFBA no dia 14/04/2014. Disponível em <https://www.youtube.com/watch?v=WfsievoON54>. Acesso em 27/08/2017.

${ }^{11}$ Sérgio Gaudenzi se formou "em Engenharia Civil pela Universidade Federal da Bahia (1967), participou da Juventude Universitária Católica e foi um dos fundadores do Clube de Engenharia da Bahia". Disponível em <http://www.fgv.br/cpdoc/acervo/dicionarios/verbete-biografico/sergio-mauricio-brito-gaudenzi>. Acesso em 27/08/2017. Foi presidente da União dos Estudantes da Bahia em 1961-1962. Foi preso e respondeu a processo judicial após o golpe de 1964.
} 
polarizada de 1968, os formandos de Economia confeccionaram um convite com citações de Che Guevara e Peter Kropotikin. Posteriormente, o convite foi usado como peça jurídica para a acusação de subversão no meio estudantil (ANEXO BNM 4204, 1968).

Dos exemplos elencados emergem questões sugestivas: qual o perfil de militante construído pelas organizações estudantis e correntes políticas? Quais as aproximações e diferenças? Havia um rígido "código" de conduta e disciplina na prática política? Como a dimensão lúdica se apresentou na ação estudantil? Quais as diferenças neste quesito entre a ação estudantil desenvolvida no pré e no pós-golpe? Como as memórias lidam com essa dimensão? É um tema-tabu silenciado por supostamente relativizar a combatividade e seriedade do movimento? Como investigar a relação entre política e festa no ME nos anos 1960? As questões justificam pesquisas sobre o comportamento estudantil que considerem esta dimensão.

Caso ainda restem dúvidas, a força desta problemática pode ser atestada pela pesquisa desenvolvida por Edmilson Alves Maia Júnior sobre os ritos políticos do ME em Fortaleza (1962-1969). Inspirado pela antropologia e buscando captar como "a política era vista pelas ações e percepções simbólicas", Maia Júnior (2008, p. 25) reflete sobre "as passeatas inserindo-as nas redes de sociabilidade do movimento estudantil”. O autor discute os sentidos das "passeatas de calouros", especialmente o desfile dos recémaprovados no vestibular "acontecendo em um sábado, com milhares de pessoas assistindo nas calçadas e praças do coração da cidade na época" (MAIA JÚNIOR, p. 178).

Amparado em entrevistas, imprensa e em um vasto acervo fotográfico, o historiador investiga esse ritual - conhecido como "Passeata dos Bichos" - entre os anos de 1962 e 1968 percebendo o seu papel de construção das múltiplas identidades dos atores e sublinhando a compreensão da ação estudantil articulada com a condição juvenil. O autor identifica na trama tensões entre os estudantes e a lógica da suspeição pós-golpe de 1964 envolvendo a Polícia e setores da imprensa diante da “imprevisibilidade" do rito e seus riscos de "desordem”. Decifra discursos reivindicatórios 
Para o autor

as manifestações estudantis dos anos 1960 foram espaços fundamentais - verdadeiros ritos políticos vividos pelos universitários. Ritos de iniciação, de coesão dos grupos políticos em torno de seus pressupostos fundadores e mesmo ritos de aglutinação como os momentos de enfrentamento com a polícia. Deles surgem o lugar da disputa, lugar do enfrentamento e o lugar da representatividade. [...] Marcos das narrativas e por isso mesmo elementos explicadores da historicidade das experiências" (MAIA JÚNIOR, 2008, p. 30).

\section{As percepções sobre os estudantes secundaristas}

Sem perder de vista a busca de uma compreensão ampla da ação estudantil e suas múltiplas dimensões, Aécio Pamponet Sampaio insere uma questão adicional para analisar o comportamento dos estudantes. Para ele, o confronto foi um combustível para a participação e radicalização estudantil: "Na hora que o couro comia era a hora que a gente se sentia feliz. Todo mundo na rua jogando pedra e disputando pedrada com a polícia. Era o grande orgasmo nosso! Era neste momento!".

A análise do entrevistado é sugestiva, haja vista que o período 1966-1968 foi contagiado por uma dialética repressão-resistência. Em muitos momentos, as passeatas estudantis pelo Brasil atraíram a violência policial. Isso gerava fato político, cobertura jornalística, denúncia da ditadura e, paradoxalmente, contribuía para o aumento da resistência estudantil. Setores da repressão política perceberam isso, como atesta o DOPS Paraná cuja orientação de ação era "evitar a repressão violenta aos estudantes, ao menos publicamente. Não criar "fatos políticos" significava não dar subsídios para a retórica de denúncia da ditadura, utilizada pela esquerda estudantil" (HAGEMEYER, 1998, p. 101).

A resistência à Lei Suplicy Lacerda que extinguiu a UNE em novembro de 1964processo de repercussão nacional - e a mobilização pela encenação de uma peça dos estudantes do Colégio da Bahia que foi reprimida pela direção da escola - evento local - 

massivo na cena pública.

Para Gey Espinheira, os estudantes secundaristas eram mais "porra-loucas" e, quando tomavam fôlego, passavam na frente dos universitários e dos partidos. Isso era resultado, segundo o entrevistado, do seu descomprometimento com objetivos formais como, por exemplo, a entrada no mercado de trabalho. ${ }^{12}$ Desse modo, eles seriam mais livres e teriam desenvolvido protestos contra uma medida muito mais próxima do cotidiano e que despertou imensa energia militante, como foi a luta contra a Lei Orgânica de 1967 - uma medida do governo estadual que foi interpretada pelo ME como tentativa de cobrança de mensalidades na rede pública de educação e gerou intensos e protestos políticos.

Isso talvez explique porque muitos dos entrevistados tenham construído suas memórias a partir dos acontecimentos relacionados a essa experiência de resistência. Gey Espinheira afirmou que "o principal ano [do movimento estudantil soteropolitano] foi 1967”. As passeatas envolvendo centenas de secundaristas na faixa etária de 15 a 18 anos junto com a presença de pais e mães, professores, estudantes universitários e intelectuais, entre outros, carimbaram a memória destas pessoas. Juca Ferreira compartilha da interpretação: "uma característica do movimento estudantil [secundarista] era que ele era muito mais de rua, mais agressivo, [...] mais combativo, mais afeito às manifestações, ao confronto. O movimento universitário era mais politizado, mais civilizado".

\footnotetext{
${ }^{12}$ Sem entrar no debate sociológico a propósito da existência de comportamentos distintos entre secundaristas e universitários, este é um espaço pertinente para uma nota historiográfica. Contrapondose a uma espécie de mito do poder estudantil universitário que operou um quase esquecimento a respeito do papel do movimento secundarista entre 1964 e 1968, Daniel Aarão Reis (1999, p. 65) considera que "os secundaristas desempenharam um papel decisivo em importantes capitais estaduais, por exemplo Belo Horizonte, Goiânia, Fortaleza, Vitória, Salvador, Maceió etc. A rigor, a história desses centros ainda está muito mal contada - e compreendida. E foi a ação deles, no entanto, que conferiu ao movimento um caráter nacional". A opção deste texto é não conferir graus de importância em relação ao papel destes sujeitos coletivos, ainda que exista a convicção de que a aliança entre ME universitário e secundarista soteropolitano construiu uma dinâmica própria, principalmente a partir da pauta e temporalidade que apresentam diferenças em relação ao ME carioca.
} 


\section{Violência, repressão política e trajetórias pessoais}

Paralelas às lutas, a violência e repressão políticas emergiram em muitos relatos a partir de diferentes pontos de vista. Além de dimensões subjetivas, a diversidade tem a ver com o período e o grau de violência. Antes do Al-5, um militante narrou ter passado um mês preso em 1966 por ter sido flagrado pela polícia colando cartazes relacionados ao Congresso da UNE. Perguntado sobre a sua prisão, Benedito Veiga apresentou suas percepções:

O que eu sinto pra mim, o que é mais importante disso tudo é que eu não me arrependo do que eu fiz, não me arrependo do que fiz e fiz por livre e espontânea vontade! Quero deixar bem claro! Ninguém nunca me obrigou a nada. Foi uma decisão minha [...] de opção minha [...] eu nunca me arrependi do que fiz [...] eu acho que minha posição seria a mesma.

Esse tema foi enfaticamente pautado pelo entrevistado. Ele mencionou que 1966 foi um "ano importante para a consolidação da ditadura" e em seguida estruturou seu depoimento a partir de reflexões sobre a sua prisão. Além de sua "cronologia da lembrança original" (François, 2001, p. 08), parece que a experiência de ter sido preso modelou o significado atribuído por ele de "grande testemunha" na história definida como sendo "aquela que construiu sua identidade sobre uma ação voluntária e conscientemente interpretada, qualquer que tenha sido seu nível de responsabilidade ou ação reais" (VOLDMAN, 2001, p. 41).

A experiência de ter ficado preso por um mês conferiu um senso de pertencimento à "militância dos anos 1960" e seus atributos de utopia na transgressão da ordem, coragem de resistir e consciência a respeito dos riscos. Isso pode ser observado em outro trecho:

[Como] havia todo um trabalho de discussão de textos, de discussão ideológica [...] ficar horrorizado, arrasado eu não fiquei [...] sou muito sincero! Agora a gente ficou sem saber o que ia acontecer. [...] Mas sofri um momento de grande aprendizado. [...] Mas era uma época [...] [em que] a opção política [...] não era de brincadeira! [...]. Como nós presumíamos do perigo que estávamos correndo, aí acho que [a prisão] não foi uma coisa assim que causou grande impacto. Em mim eu sei que não causou! 
Vale sublinhar que o ano de 1966 foi marcado por um "ciclo repressivo" (MARTINS FILHO, 1987) e violência policial no segundo semestre, mas nada comparado em amplitude ao final de 1968. O desfecho do "ano mágico" não foi favorável à oposição. Com o Al-5, o regime entrou na fase do "Terrorismo de Estado"13 (PADRÓS, 2006) repercutindo duramente no cotidiano da militância crítica à ditadura.

José Sérgio Gabrielli ${ }^{14}$ relembrou o ambiente de 1968, especialmente os protestos contra a morte do estudante Edson Luís e a violência policial, a luta por melhorias no restaurante universitário, a greve estudantil por mais verbas para a UFBA, a invasão da Faculdade de Economia, a preparação para o $30^{\circ}$ Congresso da UNE, assim como temas gerais a exemplo da Guerra do Vietnã e a invasão da Tchecoslováquia. Sublinhou 1968 como um ano de "reações desproporcionais. [Era] como enfrentar tiros de fuzis como bola de gude. Mas nós fizemos isso. Literalmente fizemos isso! Enfrentamos várias vezes [...] tiros de fuzil com bolas de gude. [...]. Essa era a sensação [...] [até] que vem o Al-5 e a desproporção entre o fuzil e a bola de gude aumenta e o fuzil se torna bem mais poderoso e avança na inibição dos movimentos [de resistência]".

O Professor Istvan Jancsó (2004) amplia a reflexão sobre o impacto do Al-5. Na UFBA, o Ato Institucional fez retroceder um rico processo de mobilização sindical dos professores. De acordo com o testemunho, diferentemente da assembleia anterior em

\footnotetext{
${ }^{13}$ Enrique Padrós tem sido o principal historiador brasileiro a sistematizar os "elementos constitutivos do Terror de Estado" (TDE) aplicado na América Latina entre os anos 1960 e 1980. Ainda que atento a diferentes modalidades repressivas aplicadas em cada caso concreto, o autor delineia aspectos gerais que contribuem para uma apreensão em conjunto da dinâmica, complexidade e abrangência dos diferentes sistemas repressivos. Dentre outros aspectos, indica a "violência irradiada", "a diluição das responsabilidades entre os funcionários que administram a máquina repressiva", "o fomento e a consolidação de uma cultura do medo", "a identificação e a exploração da figura do "inimigo interno"', "o caráter imprevisível da dinâmica do TDE", "o isolamento", "o inxílio", "a política de controle" e "a manipulação e o ocultamento de informação técnica que complementa o controle da população". Estes elementos estiveram presentes na experiência ditatorial brasileira no imediato pós-golpe, mas principalmente a partir do Al-5. Para discutir mais a noção de Terrorismo de Estado, ver o resumo feito em Padrós (2006). Uma reflexão mais densa está presente na sua tese de doutorado, especialmente no Capítulo 1 (PADRÓS, 2005).

${ }^{14}$ José Sérgio Gabrielli de Azevedo (67 anos) entrou na UFBA em 1968. Já tinha sido militante secundarista. Membro da APML, foi eleito vice-presidente do DCE em 1968 - cinco dias antes do Al-5. Tornou-se Professor da UFBA. É filiado ao PT. Foi secretário de planejamento do Estado da Bahia e Presidente da Petrobras. Depôs na décima oitiva da Comissão Milton Santos de Memória e Verdade da UFBA, realizada no dia 29 de abril de 2014, no auditório da Faculdade de Comunicação. Afirma que esteve preso oito vezes ao longo da ditadura. Disponível em <https://www.youtube.com/watch?v=2RxeobEmpBs $>$. Acesso em 19/08/2017.
} 
que cerca de trezentos professores haviam comparecido, a assembleia realizada dias depois do Ato contou com apenas “doze associados e metade da diretoria”. Além disso, Jancsó delimita a escala de observação para o ambiente acadêmico:

E como era previsível, o emaranhado de siglas, projetos, estratégias, inimizades, desconfianças e esperanças convergia para a Universidade e, em especial, para a Faculdade de Filosofia. Todas essas dificuldades tinham uma componente especialmente dolorosa: a deterioração das relações pessoais. Sólidas amizades eram abaladas; os velhos encontros de amigos eram substituídos por reuniões de "companheiros". As relações sociais tendiam a se formalizar para aqueles que passaram a ter (ou a temer nos outros) uma dimensão clandestina da vida que não poderia ser partilhada, em muitos casos sequer com a mulher ou 0 marido. A vida política, para muitos, retirou-se da esfera do público, e uma esquizofrenia assumida/imposta triturava afetos, amizades, projetos pessoais. A onipresença da ditadura tornara-se terrivelmente pesada (JANCSÓ, 2004, p. 19).

O relato sublinha o impacto do Al-5 no cotidiano universitário. Esta percepção é inovadora. Apesar de um rico texto publicado em 1998 sobre o "cotidiano da oposição de classe média no Brasil" (ALMEIDA; WEIS, 1998), a experiência da vida cotidiana, das atitudes e comportamentos sociais sob a ditadura militar brasileira ainda não frequenta a agenda historiográfica com a importância devida. Neste quesito, a historiografia argentina se alimenta com mais fartura (AGUILA, 2008; CAVIVGLIA, 2006). Certamente, o Dossiê da Revista Estudos Ibero-Americanos (2017) sobre “História, cotidiano e memória social - a vida comum sob as ditaduras no século XX" é lançado num momento oportuno. ${ }^{15}$

Retomando o foco para o impacto do Al-5, além das consequências no âmbito universitário, o protesto estudantil na cena pública foi esvaziado. Diretórios estudantis foram fechados e muitos militantes se esconderam ou foram presos. O exílio não foi possível para todos os perseguidos políticos e, mesmo para aqueles que conseguiram sair do país, organizar a vida em terra estrangeira não foi fácil. Após o Al-5, muitos ativistas políticos do movimento estudantil que ficaram no Brasil pagaram um alto preço por seu

\footnotetext{
${ }^{15}$ Disponível em http://revistaseletronicas.pucrs.br/ojs/index.php/iberoamericana/issue/view/1121/showToc $>$. Acesso em 28/08/2017.
} 
engajamento político anterior. Tiveram bolsas para estudar fora do país canceladas, foram impedidos de trabalhar no serviço público e por muito tempo tiveram dificuldades de inserção no mercado de trabalho privado ou foram demitidos. Muitos sofreram perseguição política.

Situação dolorosa fisicamente foi experimentada por Fernando Alcoforado. ${ }^{16}$ Militante estudantil até o golpe civil-militar, foi preso. Aguardou julgamento até 1970 (JOSÉ, 2000, p. 115). Nos anos 1970, viajou para o Rio de Janeiro e desenvolveu formas de solidariedade com pessoas perseguidas pela ditadura. Uma delas foi um antigo colega da Politécnica. O depoente contou que o colega "saiu de minha casa e me deixou uma mala que eu deveria entregar a uma pessoa [...] e me deixou também uma senha que eu deveria passar para um contato". Narrou ainda que quando se dirigiu ao local para entregar a mala, foi preso por agentes do DOI-CODI:

Chegamos no local [quartel do exército] [...] e lá eu já fui recebido aos socos e pontapés e a cada soco que as pessoas me davam um deles lia desde o preâmbulo até os artigos da Declaração Universal dos Direitos do Homem [...] Cada artigo era um soco! Depois te ter tomado uma surra, eles tiraram minha roupa e me colocaram numa geladeira [...] um ambiente de temperatura equivalente a alguma geladeira [...] e neste local tinha um alto-falante e emitia o som de pessoas sendo torturadas [...] exatamente para me intimidar. $\mathrm{E}$ depois de passar uns 3 dias porque a gente perde a noção de tempo num lugar desses [...] e eles não me davam nem água pra beber nem alimento, aí então me levavam pra uma sessão de tortura [...] era choque elétrico em todas as partes do corpo, era afogamento, era pau de arara [...] exatamente com a intenção de obter uma confissão ou uma delação [...] eu perdi de 15 a 30 quilos num espaço de 30 dias. [...] eu desmaiei várias vezes durante a tortura, inclusive prenderam minha mulher. Ela não passou pelos constrangimentos que eu passei.

Além de destacar a crueldade da experiência relatada, esse militante exercia um cargo importante numa companhia elétrica. Segundo a narrativa, houve mobilização envolvendo a empresa, um parlamentar e o cardeal Dom Eugênio Salles. Após 30 dias, Alcoforado foi levado para o DOPS. O objetivo dos policiais era "recuperá-lo" dos

\footnotetext{
${ }^{16}$ Fernando Alcoforado ingressou na universidade em 1963. Cursou Engenharia na Faculdade Politécnica. Compartilhou relato memorialístico no "20. Conversando sobre a história da Politécnica". Disponível em <https://www.facebook.com/apub.sindicato/videos/vb.187816627926899/1636830213025526/?type=2\&th eater $>$. Acesso em 23/08/2017.
} 
hematomas e impedi-lo de fazer exame de corpo delito para denúncia. Dias depois, o militante foi liberado, mas foi demitido da empresa por ordem do Exército.

Outro caso suscita o exame das lembranças estudantis das experiências de repressão. Aécio Pamponet Sampaio teve seu direito de matrícula cassado em 1969. Considera que "foi um corte do ponto de vista psicológico muito grande, como se tivesse tirado o chão porque a política também tinha o sentido de sustentação emocional e psicológica [...] de repente você fica sem ela, sem a possibilidade de continuar estudando. [...] O grande impacto foi a retirada da política estudantil da minha vida [...] como se tivessem me tirado algo essencial na vida. Reaprender a viver de outra forma acarretou muito sofrimento. Um período ruim! Muito ruim! Pior que o período de prisão, repressão, perseguição, pior que todas as violências que eu sofri durante o tempo que militei foram os impedimentos a partir de 1969".

Vale ressaltar que o militante não foi torturado. A narrativa atualizou o passado. Para Delgado (2006, p. 18), “fala-se de um tempo sobre um outro tempo. [...] registramse sentimentos [...] em uma narrativa entrecortada pelas emoções do ontem, renovadas ou ressignificadas pelas emoções do hoje”. O testemunho é sugestivo para a reflexão sobre as motivações subjetivas da militância, a experiência política vivida como sentimento, o papel dos laços afetivos na constituição das identidades militantes e a própria dimensão afetiva da memória.

A cassação ao direito de matrícula se estendeu a quase 80 estudantes da UFBA. Foi uma aplicação retroativa do Decreto 477 editado em fevereiro de 1969. Este decreto punia estudantes e professores que se envolvessem em manifestações de caráter “político-partidário”. Para Motta (2014, p. 154), “o 477 foi concebido para desmantelar o movimento estudantil, considerado perigoso adversário do governo no contexto dos eventos de 1968" e "os documentos mostram que algumas autoridades no comando da repressão também tinham temores, principalmente em relação à capacidade de mobilização estudantil, e mesmo após a edição do Al-5". O autor afirma ainda que "foram excluídas centenas de estudantes das universidades [brasileiras] nos primeiros meses de 1969, em proporção bastante superior ao expurgo de 1964" (MOTTA, 2014, p. 159). Os estudantes enquadrados ficaram impedidos de estudar por até 03 anos. Militante do 
PCdoB preso junto a outros ativistas na Faculdade de Direito, Vitor Hugo ${ }^{17}$ foi enquadrado na medida e enfocou especialmente a reação de alguns colegas à cassação:

Na época depois da prisão da gente, houve [uma reação] quase como se a gente tivesse meio doente, com uma doença contagiosa. Muita gente ficou com medo até do contato com a gente. [...] A militância já era clandestina, mas [a clandestinidade veio] na própria universidade. Aquelas pessoas que aceitavam a militância da gente, começam a mudar o comportamento diante de você, a não querer mais o contato. [...] Isso tudo começa a se diluir e o pessoal começa a dar sinais de que tava atemorizado e você começa a perceber [...] a frieza até que se dá o afastamento [..] Horrível! [...] Um mal-estar muito grande [...] e a gente sabia que a presença da gente ia causar, ia ser um estorvo pra muita gente. [...] E aí a gente foi se afastando

O relato ilustra a força do discurso acusatório anticomunista e da cultura do medo (PADRÓS, 2006). Goffman (1975, p. 18) argumenta que isso influencia a vida do indivíduo porque "aqueles que têm relações com ele não conseguem lhe dar o respeito e a consideração que os aspectos não contaminados de sua identidade social os haviam levado a prever e que ele havia previsto receber". O relato atenta para o impacto da ausência de solidariedade junto ao meio social em que atuava. Aproxima-se de uma espécie de exílio no próprio país, de inxílio como a

expressão do isolamento de um indivíduo que não se reconhece mais onde está, nem naquilo que faz, nem nas relações que mantém com os demais indivíduos, que sofre com o tempo indefinido e congelado do exilado, mas com a peculiaridade de que a mudança não está no distanciamento geográfico e cultural, e sim na falta de reconhecimento do seu meio social mais imediato (PADRÓS, 2006, p. 20).

\section{O militante e o estudante-comum: universos paralelos?}

Uma instigante problemática que emergiu na análise das fontes orais diz respeito à relação entre a militância de esquerda e o conjunto dos estudantes. Como se daria esse contato uma vez que a maioria dos estudantes não era organizada politicamente nem partidariamente, tampouco fazia da ação política uma opção cotidiana, um projeto de vida? A questão se torna mais pertinente quando se considera que nem o estudante-

\footnotetext{
${ }^{17}$ Vitor Hugo era aluno de Direito em 1968. Militou no PCdoB e teve seu direito de matrícula cassado.
} 

sobre o exercício militante:

exigia a disciplina, exigia o sacrifício, exigia a disposição para se preparar para a grande revolução que iria acontecer. Não era uma forma de vida ligada ao prazer. O prazer era quase algo proibitivo pra gente. O que era exaltado era a capacidade de sacrifício, de doação, de disciplina [...], de culto aos princípios revolucionários. O prazer pessoal era um sentimento pequeno-burguês. [...] [As organizações eram] corporações muito rígidas. Viver era viver em função da mística revolucionária. [...] $\mathrm{O}$ militante era um soldado da organização de esquerda. [...] e era um cotidiano tenso. [...] Você [...] deixava de ser uma pessoa-comum.

O mesmo entrevistado aponta que "o movimento satisfazia plenamente nossas expectativas [...]; então a gente se afastava muito do [cotidiano]. [...] Criava um universo nosso, [...] um universo paralelo". Essa afirmativa é sugestiva pois, sem desconsiderar as diferenças em torno do caráter da revolução, das formas de luta e da estratégia revolucionária (RIDENTI, 1993), havia uma cultura de esquerda compartilhada entre seus militantes.

Esse ideário de esquerda era crítico à ditadura e valorizava o papel da vanguarda. Enfatizava a importância da ação, do engajamento cotidiano, da disciplina e dedicação na luta política. Considerava a contribuição do ME nesse acúmulo de forças e delineava o campo estudantil como um "celeiro de quadros" para as organizações. A esse ideário compartilhado, deve-se acrescentar o contexto de polarização na disputa política já que “o clima na época era muito mais receptivo à radicalização do que à contemporização", como mencionou novamente o ex-militante que ilustrou a representação com base num fato:

o que se pedia, se ansiava era uma radicalização contra o regime e seus representantes em todos os níveis. Então, diretor de escola era agente da ditadura. A gente via as coisas assim. Nós tínhamos um professor de Ciência Política, muito bom. Chamava Navarro de Brito. [...] Foi secretário de educação [durante o governo Luís Viana] [...]. Só que ele tinha sido subchefe da casa Civil do Governo Castelo Branco. [...] Nós fizemos uma greve na escola pra botar ele pra fora. Conseguimos botar ele pra fora. 
Ele não resistiu. Até placa nós pregamos de repúdio a ele na escola. Criamos um clima em que ele não tinha condições de ensinar [...]. Isso pra nós era suficiente. Não contava a competência dele como profissional, como professor. E aí tiramos ele da escola e botamos João Ubaldo Ribeiro no lugar. [...] A greve durou mais de um mês [...] Pregamos uma placa na frente da Escola contra ele, na porta do diretório. Fomos levar moção de repúdio a ele pessoalmente na secretaria de educação. [...] Cara de pau, né? a gente foi lá: "A gente não quer mais que o senhor ensine mais, o senhor é um representante da ditadura, aprovamos por unanimidade".

Os conflitos envolvendo o ME e o Professor Navarro de Brito remetem ao desgaste político interno à Faculdade sofrido pelo professor. A trajetória de secretário de educação e a de um ex-membro do Governo Castelo Branco passou a ser um distintivo social que "contaminou" a imagem do professor, ofuscando outros atributos positivos, particularmente a sua competência profissional, segundo o relato. "Atributo profundamente depreciativo", o estigma (GOFFMAN, 1975, p. 13) foi construindo e deteriorando a identidade do docente na relação social com ativistas estudantis num contexto de radicalização política e ideológica.

Esse clima de polarização se manifestava em outras esferas do cotidiano militante. O mesmo entrevistado salientou que "era engajado até nas escolhas afetivas, os namoros [...], os interesses [...] tinha que ter cuidado para não namorar menina burguesa, pequeno-burguesa, alienada ${ }^{18}$. Tinha de ser meninas politizadas, se possível engajadas”. É importante destacar que esse militante estruturou seu depoimento a partir da autocrítica fundamentada na crítica às organizações de esquerda. No decorrer da entrevista, ele afirmou de modo contundente que

as organizações tinham uma visão muito instrumental do estudante. [...] o estudante só era objeto de atenção das organizações quando ele demonstrava algum potencial, alguma inclinação, alguma perspectiva de engajamento organizado. Quando ele se constituía numa esperança de recrutamento. O estudante-comum recebia um certo rótulo: ou era

\footnotetext{
${ }^{18}$ Aqui também uma percepção estigmatizadora. Naquele contexto, muitas relações sociais estiveram pautadas pelo estigma e por estereótipos. Para Sirinelli (2014, p. 49), "a definição mais corrente dos estereótipos é aquela de opiniões prontas e amplamente difundidas. Longe de serem puras ideias suspensas acima dos grupos humanos, elas só existem, portanto, encarnadas no seio desses grupos". Inspirado no autor, podemos afirmar que aquele contexto de radicalização política e ideológica se constituiu numa "poderosa fábrica de estereótipos" (SIRINELLI, 2014, p. 50).
} 
alienado, ou era pequeno-burguês. Aquele que não demonstrava uma certa tendência [...] "revolucionária", marxista-leninista [...] era visto um pouco com um certo desprezo e até uma dose acentuada de preconceito. Havia uma visão [...] meio patrulheira, de cobrança, de patrulhamento ideológico [...] Estudante de primeira linha para as organizações políticas que atuavam do movimento estudantil era o estudante engajado. Depois disso, o estudante que apresentava o potencial de algum dia virar quadro destas organizações. Aquele que não tinha uma formação político-ideológica afinada com as organizações, esse era visto só como massa de manobra. [...] não havia muita preocupação na formação. E a relação com ele não era [....] valorizada e até respeitosa. [...] Eu acho até que eu por ter tido militância numa organização e por ter saído, cindido com as estruturas das organizações que pertenci, eu saí com uma visão muito crítica. Eu consegui estabelecer uma relação com o estudante-comum, o estudante que não era comunista, que não era revolucionário, que não era engajado, muito boa. Eu transitava muito bem. Por que eu me sentia um pouco próximo deles [...] discriminado também pelas organizações, embora tivesse vínculo com elas.

Ao contrário de ausência de autocrítica, esse militante avaliou sua prática reconhecendo erros e criticando as organizações de esquerda. É provável que muitos militantes não concordem com o conteúdo do relato. Por isso, não se deve generalizar o teor da crítica e autocrítica descrita por Aécio Pamponet Sampaio. O depoimento foi produzido por alguém que transitou por duas organizações políticas (AP e PCB), e sua narrativa não é representativa do conjunto da esquerda. Esse militante estruturou sua entrevista a partir da crítica ao modo de agir da esquerda organizada.

Sem perder o foco da análise sobre a relação entre a militância e o estudantecomum, uma chave que nos ajuda a entender essa problemática é adotar a premissa de Martins Filho:

A análise histórica do movimento estudantil mostra como que um gráfico em que existem duas linhas: a do estudante comum e a do militante, organizado politicamente; em certos momentos existe uma aproximação, quando os setores militantes expressam as grandes aspirações da massa (MARTINS FILHO, 1997, p. 81).

Havia um relativo distanciamento entre os setores militantes e o estudante comum no plano do comportamento e estilo de vida. Ainda assim, essas esferas não eram determinantes para cristalizar um hiato de aspirações. Houve distanciamentos e 
aproximações que foram influenciados pelo contexto geral. Tomemos um exemplo. Semanas antes do golpe de 1964, emergiram conflitos no salão nobre da Reitoria durante a aula inaugural, e Pedro Castro - Tenente da Polícia Militar e presidente do Diretório Central dos Estudantes (DCE) - foi preso. Essa ação repressiva não ensejou a dialética repressão-resistência a ponto de produzir uma reação ativa de massa.

A ausência de reação ampla à prisão do Presidente do DCE sugere que o movimento estudantil local na conjuntura do golpe de 1964 não se encontrava num momento de ascensão junto à maioria dos estudantes. Esse diagnóstico parece extrapolar o contexto universitário soteropolitano. A citação é longa, mas novamente a síntese de Martins Filho (1997, p. 79-80) é esclarecedora:

Em 1961 e 62, a UNE vai estar comprometida com a luta pela reforma universitária. [...] As reivindicações estudantis deste período vão radicalizando o movimento [...]. A UNE passa a ser uma das principais organizações na Frente Nacionalista e Popular, que se forma neste período de aguda crise. [...] O nacionalismo radical que passa a se expressar nesses documentos encontrará a maior base de apoio estudantil no ano de 1962, quando da primeira greve nacional universitária, a chamada "greve por um terço". Essa greve reivindicava que o estudante tivesse um terço de assentos na direção da universidade [...] A greve no entanto foi derrotada, e dali para a frente houve um refluxo desse movimento de massa. Ao mesmo tempo, ocorria em 196364 uma radicalização da vanguarda estudantil, dos grupos militantes [...]. O movimento estudantil participará então, intensamente, de todo o processo de radicalização das lutas populares nesse período, mas não mais como um movimento de massas, e, sim, por meio de seus setores militantes, de "vanguarda", organizados, de direção.

A análise do ME na universidade baiana corrobora a afirmação do autor a respeito da ausência de um "ME de massas" na conjuntura do golpe. A única ressalva é com a periodização desse processo. O marco do distanciamento entre o conjunto dos estudantes e suas direções políticas parece ter sido em 1960, quando os estudantes baianos viabilizaram uma longa e desgastante greve contra a gestão do reitor Edgard Santos. Essa experiência de embates locais foi fundamental para a UNE incorporar na sua pauta a situação da universidade brasileira, mas o sucesso da greve para a maioria dos estudantes é questionável. Convém registrar que o I Seminário Nacional de Reforma 

"vanguarda".

Já em 1968, houve alguma aproximação entre os setores militantes e a "massa estudantil", a exemplo da greve por melhorias materiais na UFBA. Porém, quando a polarização de 1968 assumiu formas mais radicalizadas no enfrentamento à violência da polícia, sobretudo a partir de outubro, o estudante comum se afastou do ME. Isso fica nítido, por exemplo, nas passeatas com pouco número de participantes que foram realizadas em prol da libertação dos estudantes presos no Congresso da UNE, em Ibiúna.

O quadro foi amplificado após o Al-5. Aécio Pamponet Sampaio qualificou o Al-5 como um marco do atropelo histórico sofrido pela esquerda. Segundo ele, o Al-5 e o milagre econômico criaram o hiato entre os setores militantes e o estudante-comum. Disse ainda que "a massa mesmo nos ouvindo e nos admirando [...] foi capaz de perceber que a gente estava entrando numa barca furada. A massa foi mais sensível do que a gente". Ele diz que, depois disto, os principais líderes foram expulsos, a repressão foi mais intensificada e a universidade se tornou um lugar tão insuportável quanto os outros lugares, "restando para muitos a mediocridade geral [...] [e] ficar em casa assistindo televisão". O clima de medo e distanciamento foi consolidado no ano de 1969 com o endurecimento do regime em nível nacional e o cancelamento de matrículas na UFBA.

\section{As memórias de lutas e a geração 1960}

Refletir sobre as disputas políticas envolvendo a memória nos inspirou a investigar em que medida o ME buscou construir uma memória de lutas em torno de certas datas. Ao menos em 1969, o 28 de março - alusão à data da morte do estudante Edson Luís, assassinado pelas forças repressivas em 1968, no Rio de Janeiro - foi visto como um Dia Nacional de Lutas pela União dos Estudantes. A UNE, a UEB e o DCE lançaram um chamado: 
28 DE MARÇO - DIA NACIONAL DE LUTA CONTRA A REPRESSÃO DA DITADURA MILITAR.

O movimento estudantil brasileiro prepara-se valentemente para a comemoração do DIA NACIONAL DE LUTAS CONTRA A REPRESSÃO DA DITADURA MILITAR, 28 próximo, quando completará 1 ano da morte do nosso colega EDSON LUIZ DE LIMA SOUTO, assassinado covardemente na Guanabara, o ano passado pela polícia da ditadura.

A UNIÃO NACIONAL DOS ESTUDANTES - UNE - conclama a todos os colegas a participarem, a partir desta semana, das mobilizações nas faculdades e colégios em todo o território brasileiro.

A morte de Edson Luiz é chama viva no coração da juventude, como exemplo de participação na luta contra a Violência da Ditadura, contra a opressão e contra a injustiça dominantes no Brasil desde o golpe de abril de 1964 (BOLETIM AVANTE, 1969).

Este exemplo indica uma tentativa do ME em delinear a disputa em torno da sua memória e, ao mesmo tempo, buscar inspiração para a resistência à ditadura. Resta mapear em que medida esta prática foi desenvolvida nos anos posteriores, qual sua representatividade social e política e os mecanismos de circulação dessas memórias a partir de 1969.

Oliveira (2001) demonstrou o quanto a UNE reforçou uma identidade própria a partir da criação de uma mística do estudante como "um oposicionista nato" (POERNER, 1995). É interessante uma ampla agenda de pesquisa empírica que investigue como esses usos políticos do passado pelo movimento estudantil - não apenas a UNE - se associaram à construção de uma memória em torno de certos eventos históricos. A título de exemplo, investigar se as lutas em torno da Reforma Universitária no início dos anos 1960 foram incorporadas no discurso do ME pós-1964. Ao menos nas entrevistas desenvolvidas com militantes que atuaram no ME após o golpe, no discurso dos militantes na imprensa e nos poucos documentos encontrados pautando a reforma universitária, esta memória de lutas não parece ter sido acionada. Ressalte-se ainda que os militantes que começaram a participar do ME após o golpe sequer lembravam da realização destes eventos.

Sem perder de vista as características biológicas da memória e o esquecimento involuntário (IZQUIERDO, 2004), será que houve um freio na transmissão das memórias 
agenda do ME em sintonia com a alteração do contexto político. A luta pela reforma universitária, que era central para o $\mathrm{ME}$, passou para segundo plano e o foco se concentrou na autonomia das entidades estudantis. Embora em 1967 o ME tenha pautado a crítica à Lei Orgânica interpretada como uma "versão baiana" do Acordo MECUSAID para o ensino secundário pela possibilidade de instituir a cobrança de anuidades, a questão da reforma universitária só voltou a ser pautada com visibilidade em 1968. Em junho, a greve geral dos estudantes da UFBA por mais verbas para a instituição debateu o acordo MEC-USAID - em vias de implementação na UFBA desde 1965. Não obstante o que foi dito, não aparece continuidade entre estas agendas e a luta pela reforma universitária pautada a partir de 1960.

Seria equivocado desconsiderar alguns fatores que interferiram na transmissão dessas memórias das lutas gestadas antes de 31 de março, tais como a ruptura da ordem político-institucional e seus impactos no ME, a transitoriedade da condição estudantil e a nova agenda política do ME após o golpe de 1964. Sérgio Passarinho indica outro aspecto:

Quase todo o pessoal que fez movimento estudantil comigo entre $1964 \mathrm{e}$ 1968 foram pessoas que ingressaram ou em 1966 ou em 1964, que não tinham ainda ascendido a lideranças porque as lideranças pré-64 ou se formaram ou [entraram] na clandestinidade ou desaparecem [...]. Mas não se envolveram mais porque a situação era radicalmente diferente. A UEB foi extinta e nós levamos 1 ano e tanto para reorganizar [...] Os dirigentes no estado da Bahia pararam de se movimentar. Um ou outro fez algumas reuniões conosco para nos passar alguma informação.

Este relato pontua a descontinuidade entre os ativistas do ME. Algumas das lideranças do ME antes do golpe de 1964 estiveram esquadrinhadas pelo aparelho repressivo após a deposição do presidente Goulart. Muitos foram presos ou ficaram sob

19 Sob outro ponto de vista, a preocupação em torno das datas significativas para o ME se torna interessante também pelo intuito de pensarmos até que ponto o ME se apropriou de uma memória de lutas em sua prática social. Este é um tema ainda não suficientemente explorado nos estudos sobre memória, mas bastante sugestivo como atesta Jelin (2001), que, entre outros aspectos, interroga em que medida os atores ou instituições incorporam as memórias do passado em suas lutas. 
estados. Entretanto, independente do percurso, a maioria da militância estudantil que ocupava postos de direção política parece ter deixado de participar do ME como protagonista na "frente de massas". Esse fenômeno merece ser grifado e sua pertinência investigada noutras realidades.

De acordo com Maria Paula Araújo (2007, p. 155), "a direção da UNE certamente teve de ir para o exílio ou para a clandestinidade [...]. E uma nova geração substituiu os veteranos que tiveram de sair de cena". Em relato publicado em 1980, num livro de depoimentos de ex-dirigentes da entidade, Altino Dantas ${ }^{20}$, Presidente UNE (Julho 1965Julho 1966), comentou que "1964 foi marcado por uma grande repressão contra o Movimento Estudantil [...]. Fechamento de entidades, com invasão das principais, e prisão de quase toda a liderança mais ativa dos estudantes. Não foram presos os que conseguiram se exilar" (SANTOS, 1980, p. 32).

Para além da repressão política, vigilância e controle permanente, estas lideranças podem ter tido dificuldades em se adaptar ao novo contexto. Sabe-se que desde o início dos anos 1960 circulava um discurso anticomunista que depreciava o movimento estudantil, a esquerda e a UNE (DREIFUSS, 1981). Ainda assim, no caso da Universidade da Bahia, antes do golpe havia uma conotação mais positiva do que negativa em ser militante do ME perante a opinião pública. Pela elitização do acesso ao ensino superior, a condição universitária em Salvador era considerada um privilégio. A vida universitária tinha ares de glamour e distinção social: além da agenda cotidiana do ME, festas, casamentos, bailes e viagens eram noticiados na imprensa local. Muitos líderes estudantis

\footnotetext{
20 "Altino Dantas Júnior nasceu em Campo Grande, no Mato Grosso do Sul. Iniciou sua militância no movimento secundarista. No início dos anos 1960, foi diretor da União Estadual de Estudantes de São Paulo (UEE-SP) e militante do Partido Socialista Brasileiro (PSB). Foi eleito presidente da UNE em 1965 no XXVII Congresso da entidade, realizado de forma clandestina na Escola Politécnica de São Paulo Altino se revezou, na presidência da entidade, com Antônio Xavier e José Fidélis Sarno. [...] Após o fim do seu mandato, Altino deixa o PSB e entra para a resistência armada ao regime militar, na Aliança Libertadora Nacional (ALN). Foi preso em 1971. Solto após a anistia, voltou a militar pelo PSB". Disponível em < https://www.une.org.br/presidentes/altino-dantas/>. Acesso em 27/08/2017.
} 
tratados com declarado entusiasmo". Mais do que exemplos locais, a relevância dada pela grande imprensa na cobertura do ME pode ser percebida haja vista que a maioria das pesquisas que aborda o ME brasileiro nos anos 1960 utiliza o jornal como fonte privilegiada.

O golpe civil-militar implicou uma mudança de 180 graus no ME. De uma entidade socialmente reconhecida pela sociedade civil e pela opinião pública, ainda que sob fogo cerrado dos anticomunistas, a UNE foi considerada ilegal pelo governo após o golpe. A repressão política se traduziu em "operação limpeza” com destituição das direções dos diretórios estudantis, prisão e indiciamentos de ativistas em inquéritos policiais militares. Além disso, a surpresa e a perplexidade diante do novo regime são aspectos que nos ajudam a imaginar o impacto subjetivo do novo contexto para essa antiga liderança. Talvez esses fatores tenham ocasionado desestímulo e distanciamento junto ao ME que se reconstruiu entre 1965 e 1968 e aos novos ativistas que emergiram no pós-golpe. Para o ex-Presidente da UNE, Altino Dantas

A diretoria eleita no XXVII Congresso [da UNE] era composta de uma geração nova de estudantes que surgiram das bases para substituir as antigas lideranças ceifadas pela repressão. Esse aspecto vai marcar muito essa primeira gestão da UNE após o golpe; experiência e maturidade política teriam de ser adquiridas com a prática, o que levou essa diretoria a passar por grandes crises e acabar sua gestão com apenas dois diretores (SANTOS, 1980, p. 34).

Daniel Aarão Reis aponta que "o processo repressivo em geral não foi muito duro para a classe média” e que "o movimento estudantil, em particular, embora atingido, teve condições de rearticulação relativamente favoráveis. Mas a rearticulação já vai ser empreendida pela nova geração" (ARAÚJO, 2007, p. 155).

Mas há outro fator que merece ser explorado pela historiografia. Segundo um relato memorialístico publicado, muitos militantes olhavam para a liderança anterior com 
certa distância, por força da repressão política e devido a uma análise contundente a respeito da derrota para os golpistas. Em 1968: o movimento estudantil na Bahia: Um testemunho, Ubiratan Castro de Araújo ${ }^{21}$ aprofunda a questão ao reconstruir as linhas de força da crise da esquerda brasileira no pós-golpe. O ex-ativista ressalta que um “sentimento difundiu-se e consolidou-se: o desprezo aos vencidos!":

Acreditava-se que, além da força dos golpistas, as lideranças políticas do movimento popular anterior eram os responsáveis pela derrota. A crítica ao populismo desqualificava inteiramente a liderança trabalhista; a crítica ao reformismo culpabilizava os comunistas, especialmente os do Partido Comunista brasileiro, denominado por todos de Partidão para significar grande, pesado e lento, e mesmo batizado por alguns como "trambolhão histórico", ou "flamengão" (ARAÚJO, 2012, p. 89).

O alegado desprezo aos vencidos não foi absoluto, pois o autor afirma que o governo militar "prendeu e arrebentou lideranças, mas não matou nem a memória nem a transmissão militante para a geração estudantil pós-1964 da experiência de pensar em liberdade [...]. Resistir ao regime militar era acima de tudo lutar pelo direito de pensar em um padrão de qualidade da geração anterior. Basta lembrar de Wally Salomão, um dos últimos diretores culturais do CARB, em 1967, discutindo Lukács na cantina de Direito" (ARAÚJO, 2012, p. 92).

\section{Geração de 1960 equivale a geração de 1968?}

Nas linhas acima, Altino Dantas falou em "geração nova"; Daniel Aarão Reis usou “nova geração"; Ubiratan Castro preferiu "geração estudantil pós-64". É bastante

\footnotetext{
${ }^{21}$ Ubiratan Castro de Araújo "estudou no colégio do ICEIA, no bairro do Barbalho, até 1963. Completou os estudos como secundarista no Colégio Central, no centro da cidade. Iniciou seus estudos acadêmicos em 1967, no curso de História da Universidade Católica do Salvador (UCSAL) e também no curso de Direito na Universidade Federal da Bahia (UFBA). Formou-se em Direito em 1971, mas pouco advogou; sua vocação era ser historiador, graduação concluída em 1970. O cenário do início de sua vida acadêmica era o regime ditatorial, que se iniciara em 1964. Bira juntou-se à luta pela democratização do país, militando no Movimento Revolucionário 8 de Outubro (MR-8). [...]. Passou anônimo pela militância, o que o preservou da prisão e das torturas, ainda que estivesse na luta armada. Como advogado, chegou a ajudar os militantes em suas prisões, inclusive em parceria com a advogada Ronilda Noblat. Sua militância persistiu, posteriormente, na causa negra e nos rumos do Partido dos Trabalhadores". Disponível em <http://www.poisze.net/bira/Biografia/>. Acesso em 28/08/2017.
} 
O que separa uma geração de outra? Geração de 1960 é igual a geração de 1968?

Robert Darnton (1987) define geração como experiência compartilhada a partir de eventos significativos que moldaram as identidades individuais e coletivas. Para o historiador René Rémond (2003, p. 449), “o acontecimento solda uma geração, e sua lembrança continuará sendo até o último suspiro uma referência carregada de afetividade, positiva ou negativa, até que, com o desaparecimento desta, ele mergulha na inconsciência da memória coletiva, onde continuará, no entanto, a exercer alguma influência insuspeitada".

Já Sirinelli (2001, p. 134) considera que "a geração é de fato uma peça importante na engrenagem do tempo"; que possui elasticidade "devendo-se banir qualquer visão pitagórica das gerações"; e "que a história ritmada pelas gerações é uma 'história em sanfona', dilatando-se ou encolhendo-se ao sabor da frequência dos fatos inauguradores". Defende "a geração concebida como uma escala móvel do tempo" (p. 135) e "uma estrutura que a análise histórica deve levar em consideração, o que [...] contribui [...] para reabilitar o acontecimento". Argumenta, portanto, a possibilidade de "gerações criadas ou modeladas por um acontecimento inaugurador". Conclui que "a geração existe no território do historiador, ao mesmo tempo como objeto de história e como instrumento de análise" (SIRINELLI, 2001, p. 137).

No caso em tela, estas são ideias instigantes para discutir geração sem focar na faixa etária. Qual o impacto do acontecimento para moldar a noção de geração? Qual experiência foi significativa para conferir singularidade e distinção à geração de 1960 e/ou à geração de 1968? Por que se usa pouco a expressão "geração de 1964"?

Para o Vice-Presidente da entidade em 1964, Marcello Cerqueira"22, "a UNE tinha um exercício absolutamente livre e criativo. Foi na nossa geração que o movimento

\footnotetext{
22 “Em 1957, Marcelo Cerqueira filiou-se a Juventude Comunista. Foi um dos fundadores do Centro Popular de Cultura (CPC) e da revista Movimento da União Nacional dos Estudantes (UNE). Quando José Serra foi eleito presidente da UNE em 1964, Cerqueira assumiu a vice-presidência da entidade. Nesse ano, no
} 
estudantil criou a nova imprensa universitária, O CPC, o teatro popular, teve enorme influência na música jovem e no Cinema Novo. Era uma fase de intensa criatividade" (CERQUEIRA, 2011, p. 275). Daniel Aarão Reis sublinha que "foi uma coisa muito melancólica. A vitória do golpe me despertou muito inconformismo, aquele desmoronamento, aquela derrota sem resistência. E isso eu tenho a impressão que foi muito compartilhado pela minha geração politizada de esquerda" (ARAÚJO, 2007, p. 153).

Relatos com ângulos diferentes. Um positiva a experiência; outro enfatiza a derrota. Há ainda uma visão que associa 1960 a 1968 criando uma “unidade imaginária”. Irene Cardoso (2005, p. 103) critica o

mito dos anos de 1960 e de sua geração, diluindo a complexidade, a heterogeneidade, os conflitos, as heranças e a contextualização histórica dos movimentos. A construção do mito obscurece os traços das experiências de revolta e transforma em identidade o que foi pluralidade e movimento de desidentificação. Desse modo, é construída a figuração identitária da geração dos anos de 1960 ("a geração 68"), a caricatura, cujos traçados expressam a simplificação do que veio sendo assimilado e normalizado.

Talvez seja mais sugestivo tentar compreender que o golpe de 1964 foi um acontecimento que moldou a militância estudantil de modo diferenciado. Não por acaso, ainda que com algum nível de ambiguidade, a militância frisa diferenças e descontinuidades na direção do ME após o golpe de 1964. Isso é um indício de que o evento foi lido de modo heterogêneo pelos sujeitos, proporcionou sensações e lições diferentes e isso se reflete nas narrativas: seletividade da memória e relação entre fatos e representações.

Associar geração de 1960 à geração de 1968 não implica aceitar a memória da derrota construída no acerto de contas que a esquerda brasileira fez consigo mesma para

entanto, depois do golpe militar, foi obrigado a exilar-se e seguiu primeiramente para Bolívia, depois Chile e, finalmente, Europa. Em 1965, Cerqueira retornou ao Brasil, onde foi preso por cem dias. Depois de solto, retomou os estudos da faculdade, encerrando o curso ainda no mesmo ano. No início de sua vida profissional, dedicou-se a advogar em causa própria, nos processos em que estava envolvido, e foi defensor, sem cobrar honorários, de um número superior a mil pessoas processadas pela Lei de Segurança Nacional e também de inúmeros "desaparecidos políticos". Em 1968, ano de decretação do Ato Institucional $n^{\circ} 5$ (Al-5), concluiu o doutorado pela Faculdade Nacional de Direito". Disponível em <http://www.une.org.br/2011/08/marcelo-cerqueira/>. Acesso em 27/08/2017. Seu relato foi publicado em 1989 na $1^{\text {a }}$ edição de Moraes (2011). 
lidar com o trauma de 1964 ? $^{23}$ No caso do ME, este balanço apresenta indícios de que contribuiu para silenciar/frear a memória de lutas estudantis antes do golpe e imputar a essa militância anterior o estigma da derrota. O esquecimento seria o vigor da memória e “o êxito de uma censura indispensável à estabilidade e à coerência da representação que [...] os membros de um grupo fazem de si próprios" (CANDAU, 2011, p. 127). Ou seja, a construção da geração de 1968 como combativa talvez tenha silenciado/apagado a memória de lutas estudantis antes do golpe.

Parece ser mais promissor distinguir entre aqueles estudantes com militância anterior a 1964 e os novos ativistas que reorganizam o ME após o golpe com seu ápice em 1968. Ambos os grupos foram marcados de modo singular pelo evento (golpe de 1964). A militância de 1964 sofreu diretamente as angústias da derrota e da memória construída sobre a "resistência que não houve" (ARAÚJO, 2007, p. 153). Esse é um argumento presente no memorialismo político sobre o período e na historiografia. A autora toma como referência o relato de Daniel Aarão Reis a respeito das suas sensações no imediato pós-golpe: "Não houve nenhuma ação contra aquela situação que estava se desenhando. Não houve, no movimento estudantil, nenhuma articulação, nenhuma manifestação. Foi uma coisa muito impressionante" (ARAÚJO, 2007, p. 153).

Há exagero na narrativa generalizante de que "nenhuma ação, [...] articulação, [...] manifestação" foi desenvolvida. Na Universidade da Bahia, houve iniciativas fragmentadas de setores militantes. Amílcar Baiardi ${ }^{24}$ relembra que

houve uma tentativa de resistência armada em Cruz das Almas. Os estudantes se mobilizaram, reuniram armas de fogo e coquetel molotov. Pensamos em assaltar o tiro de guerra e começar uma resistência, mas tudo isso era em função de existir resistência em Feira de Santana onde [Francisco Pinto] era prefeito e em Vitória da Conquista onde Pedral [Sampaio] era prefeito, mas, como não houve resistência, então nós nos desmobilizamos e aí cada um procurou se esconder.

\footnotetext{
${ }^{23}$ Velasco e Cruz (1994) indica que a esquerda brasileira se fragmentou ao se debruçar sobre dois temas após o golpe de 1964: "as razões do fracasso e os caminhos a seguir".

${ }^{24}$ Amílcar Baiardi era estudante da Escola de Agronomia. Neste período, militava na POLOP. Na sessão realizada no dia 4 de fevereiro de 2014, no auditório da Faculdade de Comunicação, Amílcar Baiardi deu seu depoimento relatando fatos vividos no contexto do período do golpe de 1964. Disponível em <https://www.youtube.com/watch?v=xCFQCfnPvDY>. Acesso em 22/08/2017.
} 
Apesar da hipérbole de Daniel Aarão Reis, esses gestos locais não tiveram ampla repercussão, tampouco representatividade social e política. A construção do relato de Baiardi responsabiliza o outro pela ausência da resistência. Não seria isso um tema constrangedor na memória da militância de 1964, uma "área cinzenta" da memória? (PORTELLI, 2001). Essa "memória envergonhada" se aproxima da consequência apresentada por Gandau (2011, p. 130): “Às vezes, em razão de querer esquecer um período de sua história, corre-se o risco de se tornar o próprio 'esquecido da história”,. Não seria esse o caso dessa militância de 1964 que talvez não se reconheça positivamente como a "geração de 1964"?

No outro extremo, a militância estudantil de 1968 emergiu na oposição à ditadura, se reconhece como uma geração, mas "a experiência de revolta dessa geração tem uma história e uma memória"; tem, portanto, "uma filiação":

Como em toda herança, algo se impõe à geração seguinte - ideais, modos de pensar, visões de mundo - e é recebido antes mesmo de ser escolhido, o que constituiria seu aspecto de passividade. No entanto, a herança não se restringe a essa característica: outra, talvez mais importante, é a da escolha daquilo que é recebido. Essa escolha é o movimento que parte de uma decisão de reafirmar a herança, não apenas aceitá-la, mas "relançá-la de outra maneira", reinterpretá-la, criticá-la, deslocá-la, transformá-la. Diante dessa dupla injunção pode-se falar, então, na possibilidade de uma filiação (CARDOSO, 2005, p. 100).

Essa filiação teria sido acompanhada de herança e de escolhas. Para Franklin Martins 25 , a luta armada pós-Al-5 foi “a resposta ao trauma de 1964, quando em 1964 não se reagiu, não se fez nada. Quando veio 1968, a reação foi: “Agora nós vamos reagir”" (ARAÚJO, 2007, p. 195). Ao mesmo tempo, uma escolha parece ter sido o distanciamento da liderança anterior, pesada pelo fardo da "resistência que não houve" e estigmatizada como derrotada, seja pelos vencedores ${ }^{26}$, seja por setores da esquerda. De acordo com Juca Ferreira:

\footnotetext{
${ }^{25}$ Franklin Martins estudou no Colégio de Aplicação no Rio de Janeiro. Estudou Ciências Econômicas na UFRJ (antiga Universidade do Brasil). Foi presidente do DCE da Universidade e vice-presidente da União Metropolitana dos Estudantes do Rio de Janeiro. Militou na Dissidência Universitária da Guanabara e no MR-8. Participou da operação de sequestro do Embaixador dos Estados Unidos, Charles Elbrick, em 1969.

${ }^{26}$ Por exemplo, o Jornal A Tarde veiculou no imediato pós-golpe diversas charges em tom de deboche da esquerda e da ausência de resistência.
} 
A gente olhava pra frente, o tempo inteiro. É, inclusive, isso era próprio da idade da gente. Jovem não tem passado [...] Pelo contrário, o passado pesa nas costas. A gente tinha acabado de vir de um golpe militar, onde a esquerda fracassou, a UNE foi desbaratada. Então a gente gritava: "a UNE somos nós", "viva a UNE", "pela reorganização da UNE", ou da UBES, da União Brasileira de Estudantes Secundários e das entidades, mas olhando para frente [...] A gente não tinha muito o sentimento de continuidade, pelo contrário, a gente tinha muito sentimento de ruptura. Não só é próprio da idade, como é próprio dos anos 60, né? Os anos 60 eram anos de rupturas... Então acho que isso era marcante. Nós não olhávamos muito pra trás. Não tínhamos muito sentimento de historicidade. Olhávamos pra frente, para a possibilidade de transformação, para o futuro.

A narrativa reitera o desprezo pela "esquerda [que] fracassou", por suas experiências, acúmulos e vitórias. Acrescenta uma sensação de "presente contínuo" (Hobsbawm, 1995) que, somada aos aspectos já elencados acima, parece ter contribuído para a descontinuidade e o freio da transmissão de memórias de lutas. Analisar a subjetividade desses ativistas de 1968 e em que medida a valorização da ação e o ceticismo em relação às experiências da militância anterior foram traços distintivos é um caminho fértil para problematizar a construção em torno da geração de 1968.

$$
* * *
$$

É necessário aprofundar investigações que problematizem as memórias estudantis sobre os anos 1960 e investigue além dos tópicos elencados - política e festa; trajetórias pessoais impactadas pelo golpe de 1964 e pelo Al-5; relação entre setores militantes e o estudante-comum, comportamento dos estudantes secundaristas e universitários. Isso pode levar a revisitar a homogeneização em torno da "geração de 1960", sua associação íntima com geração de 1968 e sua periodização focada em 1968. Essa construção tem um sentido mítico, seleciona a experiência de contestação enquanto metade da década parece perdida (1960-1964). É uma memória que se conecta com a mitologia a respeito da filiação contestatória da juventude dos anos 1960. Afinal, "a possibilidade de receber e escolher a herança, de estabelecer continuidades e diferenças, de relançá-la de outros modos implica o movimento de separação das gerações, de produção de uma diferença geracional - condição de uma filiação possível” (CARDOSO, 2005, p. 105). 
Lidar com as diferentes periodizações, eventos e experiências na década de 1960 é importante para dar visibilidade à militância estudantil que atuou antes do golpe de 1964 . Convém interrogar em que medida se conformou uma geração de 1968 que selecionou eventos e contribuiu para apagar da memória experiências e lutas desenvolvidas pela militância de 1964 ou imputar-lhe a marca da derrota. Feito isso, analisar suas eventuais continuidades e rupturas pode contribuir para restituir a complexidade e riqueza dos anos 1960, problematizar as memórias e agenciar problemáticas que construam novos capítulos da história do movimento estudantil brasileiro.

\section{Referências}

AGUILA, Gabriela. Dictadura, represión y sociedade em Rosario, 1976/1983: um estudio sobre la represión y los comportamentos y actitudes sociales en ditadura. Buenos Aires: Prometeu Libros, 2008.

ALCAZAR I GARRIDO, Joan Del. As fontes orais na pesquisa histórica: uma contribuição ao debate. Revista Brasileira de História, São Paulo, v.25, n.6, 1993.

ALMEIDA, Maria Hermínia Tavares de; WEISS, Luiz. Carro-zero e pau-de-arara: o cotidiano da oposição de classe média ao regime militar. In: SCHWARCZ, Lilia Moritz (Org.). História da vida privada no Brasil: volume 4. São Paulo: Companhia das Letras, 1998.

ARAÚJO, Maria Paula. Memórias estudantis, 1937-2007: da fundação da UNE aos nossos dias. Rio de Janeiro: Relume Dumará: Fundação Roberto Marinho, 2007.

ARAÚJO, Ubiratan Castro de. 1968 o movimento estudantil na Bahia: um testemunho. Revista Perspectiva Histórica. v.2, n.3, p. 85-96, Jul./dez., 2012.

BOSI, Eclea. Memória e sociedade: lembranças de velhos. São Paulo: T. A. Queiroz Editor: EDUSP, 1983.

BRITO, Antonio Mauricio Freitas. O golpe de 1964: o movimento estudantil na UFBA e a resistência à ditadura militar (1964-1968). 2008. Tese (Doutorado em História) - UFBA, Salvador, 2008. 
BRITO, Mauricio. Capítulos de uma história do movimento estudantil na UFBA (19641969). Salvador: EDUFBA, 2016.

CANDAU, Joel. Memória e identidade. São Paulo: Contexto, 2011.

CARDOSO, Irene. Maria Antônia: o edifício de n. 294. In: MARTINS FILHO, João Roberto (Org). 1968 faz 30 anos. São Paulo: Editora da UFSCar, p. 27-48, 1998.

CARDOSO, Irene. A geração dos anos de 1960: o peso de uma herança. Tempo Social, v. 17, n. 2, p. 93-107, nov. 2005.

CAVIGLIA, Mariana. Dictadura, vida cotidiana y classes medias: uma sociedade fracturada. Buenos Aires: Prometeo Libros, 2006.

CERQUEIRA, Marcello. O parlamentarismo teria evitado o golpe. In: MORAES, Dênis. A esquerda e o golpe de 1964. 3. ed. São Paulo: Expressão Popular, 2011, p. 273-279.

CHAUVEAU, Agnès; TÉTARD, Philippe. Questões para a história do presente. São Paulo: EDUSC, 1999.

DARNTON, Robert. Boemia literária e revolução: o submundo das letras no Antigo Regime. São Paulo: Companhia das Letras, 1987.

DELGADO, Lucilia de Almeida Neves. História oral: memória, tempo, identidades. Belo Horizonte: Autêntica, 2006

DREIFUSS, René A. 1964: a conquista do estado: ação política, poder e golpe de classe. 3. ed. Petrópolis: Vozes, 1981.

FERREIRA, Marieta de Moraes. História oral e tempo presente. In: MEIHY, José Carlos Sebe Bom (Org.). (Re) introduzindo a história oral no Brasil. São Paulo: Xamã, 1996.

FRANÇOIS, Etienne. A fecundidade da história oral. In: FERREIRA, Marieta de Moraes; Amado, Janaína (Orgs.). Usos \& abusos da história oral. Rio de Janeiro: Editora Fundação Getúlio Vargas, 2001, p. 03-13.

GALLIAN, Dante Marcello Claramonte. A memória do exílio: reflexões sobre interpretações de documentos orais. In: MEIHY, José Carlos Sebe Bom (Org.). (Re) introduzindo a história oral no Brasil. São Paulo: Xamã, 1996.

GOFFMAN, Erving. Estigma: notas sobre a manipulação da identidade deteriorada. Rio de Janeiro: Zahar Editores, 1975. 
HAGEMEYER, Rafael Rosa. 1968: o ano da derrubada do ensino pago no Paraná. In: MARTINS FILHO, João Roberto (Org). 1968 faz 30 Anos. São Paulo: Editora da UFSCar, 1998, p. 95-128.

HOBSBAWM, Eric. Era dos Extremos : o breve século XX (1914-1991). São Paulo: Companhia das Letras, 1995

IZQUIERDO, Ivan. A arte de esquecer. Rio de Janeiro: Vieira \& Lent, 2004.

JANCSÓ, Istvan. Memorial. Mimeo. 2004.

JELIN, Elizabeth. Exclusión, memorias y luchas políticas. In: MATO, Daniel (org.). Estudios latino americanos sobre cultura y trasformaciones sociales en tiempos de globalización. Buenos Aires, CLACSO, 2001.

JOSÉ, Emiliano. Galeria F: lembranças do Mar Cinzento. São Paulo: Casa Amarela, 2000.

MAIA JÚNIOR, Edmilson Alves. Memórias de luta: ritos políticos do movimento estudantil universitário (Fortaleza, 1962-1969). Fortaleza: Edições UFC, 2008.

MARTINS FILHO, João Roberto. Movimento estudantil e ditadura militar no Brasil: 19641968. Campinas: Papirus, 1987.

MARTINS FILHO, João Roberto. A rebelião estudantil: 1968 - México, França e Brasil. Campinas, Editora Mercado de Letras, 1996.

MARTINS FILHO, João Roberto. O movimento estudantil na conjuntura do golpe. In: TOLEDO, Caio Navarro (Org.). 1964 visões críticas: democracia e reformas no populismo. Campinas: Editora Unicamp, 1997.

MARTINS FILHO, João Roberto. 1968 faz 30 Anos. São Paulo, Editora da UFSCar, 1998.

MARTINS FILHO, João Roberto. O movimento estudantil nos anos 1960. In: FERREIRA, Jorge; REIS, Daniel Aarão. Revolução e democracia. Rio de Janeiro: Civilização Brasileira, 2007.

MOTTA, Rodrigo Patto Sá. As universidades e o regime militar: cultura política brasileira e modernização autoritária. Rio de Janeiro: Zahar, 2014.

MÜLLER, Angélica. 1968: memória dos atores e seus reflexos. História Oral (Rio de Janeiro), v. 10, p. 51-64, 2007. 
MÜLLER, Angélica. A história como arma: a memória histórica como objeto da resistência estudantil contra a ditadura militar no final dos anos 1970. In: DELGADO, Lucília; FERREIRA, Marieta (Orgs). História do tempo presente. Rio de Janeiro: Editora FGV, 2014, p. 81-97.

OLIVEIRA, José Alberto Saldanha. O mito do poder jovem: a construção da identidade da UNE. 2001. Tese (Doutorado em História) - UFF, Rio de Janeiro, UFF, 2001.

PADRÓS, Enrique Serra. Como el Uruguay no hay...: terror de Estado e segurança nacional, Uruguai (1968-1985): do Pachecato à ditadura civil militar. 2005. Tese (Doutorado em História) - UFRGS, Porto Alegre, 2005.

PADRÓS, Enrique Serra (Org.). As ditaduras de segurança nacional: Brasil e Cone Sul. Porto Alegre: CORAG; Comissão do Acervo de Luta contra a Ditadura, 2006.

POERNER, Artur. O poder jovem: história da participação política dos estudantes brasileiros. São Paulo: Centro de Memória da Juventude, 1995.

POLLACK, Michael. Memória, esquecimento e silêncio. Estudos Históricos. Rio de Janeiro, v. 2. n. 3, p. 3-15, 1989.

POLLACK, Michael. Memória e identidade social. Estudos Históricos. Rio de Janeiro, v. 5, n. 10, p. 200-212, 1992.

PORTELLI, Alessandro. O massacre de Civitella Val di Chiana: mito, política, luto e senso comum. In: FERREIRA, Marieta de Moraes; AMADO, Janaína (Orgs.). Usos \& abusos da história oral. Rio de Janeiro: Editora Fundação Getúlio Vargas, 2001.

REIS, Daniel. Ditadura militar, esquerdas e sociedade. Rio de Janeiro: Jorge Zahar Editor, 2002.

REIS FILHO, Daniel Aarão. 1968, o curto ano de todos os desejos. In: VIEIRA, Maria; GARCIA, Marco. Rebeldes e contestadores. São Paulo: Editora Fundação Perseu Abramo, 1999, p. 61-71.

RÉMOND, René (Org.). Por uma história política. Rio de Janeiro: Editora FGV, 2003.

RIDENTI, Marcelo. O fantasma da revolução brasileira. São Paulo, UNESP, 1993.

RIDENTI, Marcelo. Em busca do povo brasileiro. Rio de Janeiro: Record, 2000. 
ROUSSO, Henry. A memória não é mais o que era. In: FERREIRA, Marieta de Moraes; AMADO, Janaína (Orgs.). Usos \& abusos da história oral. Rio de Janeiro, Editora Fundação Getúlio Vargas, 2001.

SANTOS, Nilton (Org.). História da UNE. São Paulo: Ed. Livramento, 1980.

SILVA, Justina Iva. Estudantes e política: estudo de um movimento (RN 1960-1969). São Paulo: Cortez, 1989.

SILVA, Márcia Pereira da. Em busca do sonho: história, juventude e repressão (Franca 1960-1970). Montes Claros: Ed. UNIMONTES, 2001.

SILVA, Sandra Barbosa da. Ousar lutar, Ousar vencer: histórias da luta armada em Salvador (1969-1971). 2004. Dissertação (Mestrado em História) - UFBA, 2004.

SIRINELLI, Jean-François. A geração. In: FERREIRA, Marieta de Moraes; AMADO, Janaína (Org.). Usos \& abusos da história oral. Rio de Janeiro: Editora Fundação Getúlio Vargas, 2001, p.131-137.

SIRINELLI, Jean. Abrir a história: novos olhares sobre o século XX francês. Belo Horizonte: Autêntica Editora, 2014.

VELASCO e CRUZ, Sebastião. 1968: movimento estudantil e crise na política brasileira. Revista de Sociologia e Política. n.2, p. 37-55, 1994.

VICENTE, Keides Batista. Retratos de Goiás: memórias de ex-militantes estudantis goianos sobre a década de 1960. 2006. Dissertação (Mestrado em História) - Universidade Federal de Uberlândia, 2006.

VOLDMAN, Daniele. Definições e usos. In: FERREIRA, Marieta de Moraes; AMADO, Janaína (Orgs.). Usos \& abusos da história oral. Rio de Janeiro: Editora Fundação Getúlio Vargas, 2001, p. 33-41.

VOLDMAN, Daniele. A invenção do depoimento oral. In: FERREIRA, Marieta de Moraes; AMADO, Janaína (Org.). Usos \& abusos da história oral. Rio de Janeiro: Editora Fundação Getúlio Vargas, 2001a, p. 247-265. 
Recebido em 31/03/2017 Aprovado em 08/08/2017

Universidade do Estado de Santa Catarina - UDESC Programa de Pós-Graduação em História - PPGH

Revista Tempo e Argumento Volume 09 - Número 21 - Ano 2017 tempoeargumento@gmail.com 